\title{
Aplikasi pupuk organik terhadap hasil kacang hijau (Vigna radiate L.) di ultisol
}

\section{Organic fertilizer application on the yield green bean (Vigna radiate $\mathbf{L}$.) in ultisol}

Diterima : 15 November 2016/Disetujui : 15 Desember 2016 / Dipublikasikan : 30 Desember 2016

CDepartment of Crop Science, Padjadjaran University

\begin{abstract}
Green bean production in Indonesia has still low production and limited cultivated land, so extension land area by optimizing ultisol as marginal land is prospect. The objective of this study was to find out the green bean variety and types of organic fertilizer which gain the high yield in ultisol. The study was conducted in polybags in Screen House, Faculty of Agriculture, Universitas Jenderal Soedirman in July-September 2015. Randomized Complete Block Design (RCBD) with two factors of variety i.e. Vima 1, Betet, and Murai and type of organic fertilizer, i.e. without fertilizer (control), chicken manure, cow rumen Bokashi fertilizers and vegetable waste Bokashi fertilizer were tested. Observed variables were number of branch per plant, number of filling pod per plant, and grain weight per plant, weight of 100 grain and harvest index. The result showed that application of organic fertilizer of chicken manure and cow rumen bokhasi fertilizer obtained the high yield of green bean.
\end{abstract}

Keywords: Green bean · Organic fertilizer · Ultisol

Sari Permasalahan budidaya kacang hijau di Indonesia adalah produktivitas yang masih rendah dan lahan budidaya yang terbatas, sehingga dapat diatasi dengan mengoptimalkan lahan marginal seperti tanah ultisol untuk kegiatan budidaya kacang hijau. Tujuan penelitian ini adalah untuk mengetahui varietas kacang hijau dan jenis pupuk organik yang mampu menghasilkan produksi tinggi di tanah ultisol. Penelitian dilakukan menggunakan

Dikomunikasikan oleh Ahadiyat Yugi Rahayu

Widiyawati, I. · T. Harjoso · T. T. Taufik

Program Studi Agroteknologi, Fakultas Pertanian,

Universitas Jenderal Soedirman

Jl. Dr. Soeparno No. 61 Purwokerto, Kabupaten

Banyumas, Jawa Tengah 53123

Korespondensi e-mail: idawidiyawati87@gmail.com polibag di Screen House, Fakultas Pertanian, Universitas Jenderal Soedirman pada bulan JuliSeptember 2015. Penelitian menggunakan Rancangan Acak Kelompok Lengkap (RAKL) dengan dua faktor. Faktor pertama adalah varietas kacang hijau yang terdiri atas tiga varietas, yaitu Vima 1, Betet, dan Murai. Faktor kedua adalah jenis pupuk, yaitu tanpa pupuk (kontrol), pupuk kandang ayam, pupuk bokashi rumen sapi, dan pupuk bokashi limbah sayuran pasar. Variable yang diamati antara lain jumlah cabang per tanaman, jumlah polong isi per tanaman, bobot biji per tanaman, bobot 100 biji, dan indeks panen. Hasil penelitian menunjukkan bahwa pupuk organik kandang ayam dan pupuk bokhasi rumen sapi mampu meningkatkan hasil kacang hijau.

Kata kunci: Kacang hijau $\cdot$ Pupuk organik · Ultisol

\section{Pendahuluan}

Kacang hijau (Vigna radiata L.) merupakan salah satu komoditas pertanian yang memiliki prospek sangat baik dikembangkan di Indonesia. Kacang hijau menjadi komoditas tanaman legum terpenting ketiga setelah kedelai dan kacang tanah. Salah satu penyebabnya adalah permintaan yang terus meningkat untuk konsumsi dan industri olahan (Kementerian Pertanian, 2012).

Permasalahan utama budidaya kacang hijau di Indonesia adalah produktivitas yang masih rendah dan lahan budidaya yang terbatas. Permasalahan ini dapat diatasi dengan mengoptimalkan lahan marginal seperti tanah ultisol untuk kegiatan budidaya kacang hijau. Tantangan pengembangan kacang hijau di lahan marginal adalah peningkatan produktivitas dan mempertahankan kualitas lahan untuk berproduksi secara berkelanjutan. 
Penggunaan varietas unggul merupakan salah satu komponen teknologi untuk pengembangan produktivitas kacang hijau. Varietas unggul merupakan hasil introduksi, persilangan, mutasi atau varietas lokal. Hasil ratarata varietas kacang hijau berkisar antara 0.901.98 ton/ha dengan ukuran biji (bobot 100 biji) 2.5-7.8 g, dan umur panen antara 51-100 hari (Trustinah et al., 2014)

Tanah ultisol termasuk bagian terluas dari lahan kering di Indonesia, sekitar 45,8 juta ha. Tanah ultisol dikenal sebagai tanah dengan kandungan hara, bahan organik, dan $\mathrm{pH}$ rendah. Menurut Hardjowigeno (1993), kandungan unsur hara seperti $\mathrm{P}$ dan $\mathrm{K}$ sering kahat pada tanah ultisol, sehingga tanaman tumbuh kurang baik. Kendala yang ada pada tanah ultisol dapat dikurangi dengan meningkatkan keberadaan bahan organik (Ardjasa, 1994). Penggunaan kompos dapat meningkatkan porositas, aerasi, komposisi mikroorganisme tanah, meningkatkan daya ikat tanah terhadap air, mencegah lapisan kering pada tanah, menghemat pemakaian pupuk kimia menjadi satu alternatif pengganti pupuk kimia bersifat multiguna dan multilahan (Murbandono, 2000).

Dinesh et al. (2010) menyatakan bahwa aplikasi bahan organik dapat memperbaiki struktur tanah, meningkatkan kapasitas mena-han air, dan meningkatkan kehidupan biologi tanah. Menurut Sevindrajuta (2012), pemberian pupuk kandang sebagai bahan organik dapat meningkatkan kandungan C-organik pada tanah yang dapat meningkatkan atau malah menu-runkan $\mathrm{pH}$ tanah. Kotoran ayam merupakan sumber hara yang penting karena mempunyai kandungan nitrogen dan fosfat yang lebih tinggi dibandingkan pupuk kandang lain (Melati, 2005).

Rumen sapi merupakan organ bagian penting meliputiruang pra pencernaan untuk simbiosis mikroorganisme hidup yang memiliki fungsi membantu mempercepat pemecahan bahan makanan pada hewan ternak. Isi rumen sapi merupakan limbah dari rumah pemotongan hewan $(\mathrm{RPH})$ yang belum banyak dimanfaatkan. Isi rumen sapi dapat dimanfaatkan sebagai bahan dasar pembuatan pupuk organik cair karena rumen sapi mengandung senyawa sellulosa dan lignin (Utomo, 2015).

Pemanfaatan sampah organik dari pasar untuk dibuat kompos akan membantu menga-tasi masalah limbah pasar yang mencemari lingkungan. Kompos yang dibuat dari limbah pasar akan mengurangi ketergantungan terhadap pupuk anorganik yang harganya semakin meningkat.
Bahan organik dari limbah pasar merupakan alternatif untuk meningkatkan kesuburan tanah dan efisiensi biaya (Setiawan, 2009).

Penggunaan pupuk organik dan varietas unggul pada penelitian ini diharapkan mampu mengurangi kendala budidaya pada tanah ultisol dan meningkatkan produksi kacang hijau. Penelitian ini bertujuan untuk mengetahui varietas kacang hijau dan jenis pupuk organik yang mampu meningkatkan hasil kacang hijau di tanah ultisol.

\section{Bahan dan Metode}

Penelitian dilakukan menggunakan polibag di Screen House, Fakultas Pertanian, Universitas Jenderal Soedirman pada bulan Juli-September 2015. Penelitian menggunakan Rancangan Acak Kelompok Lengkap (RAKL) dengan dua faktor. Faktor pertama adalah varietas kacang hijau yang terdiri dari tiga varietas, yaitu Vima 1, Betet, dan Murai. Faktor kedua adalah jenis pupuk, yaitu tanpa pupuk (kontrol), pupuk kandang ayam, pupuk bokashi rumen sapi, dan pupuk bokashi limbah sayuran pasar. Pupuk yang diberikan adalah $80 \mathrm{~g} /$ polibag atau setara dengan 20 ton/ha. Tanah ultisol yang digunakan dalam penelitian diambil dari kecamatan Somagede, Banyumas. Hasil pengamatan dianalisis varians dan dilanjutkan uji perbandingan antar rerata dengan DMRT. Parameter hasil dan komponen hasil yang diamati antara lain jumlah cabang per tanaman, jumlah polong isi per tanaman, bobot biji per tanaman, bobot 100 biji, dan indeks panen.

\section{Hasil dan Pembahasan}

Hasil analisis tanah awal sebelum perlakuan menunjukkan bahwa tanah ultisol yang digunakan dalam penelitian termasuk masam, terlihat dari $\mathrm{pH}$ tanah yaitu 5,47. Kandungan $\mathrm{C}$ organik, $\mathrm{N}$ total, dan $\mathrm{K}_{2} \mathrm{O}$ tersedia juga sangat rendah. Kandungan unsur $\mathrm{P}$ sebenarnya sangat tinggi yang terlihat dari hasil analisis pada parameter $\mathrm{P}_{2} \mathrm{O}_{5}$ total, tetapi $\mathrm{P}_{2} \mathrm{O}_{5}$ yang tersedia sangat rendah. Salah satu kendala utama dalam pemanfaatan Ultisol untuk pertanian adalah rendahnya ketersediaan dan efisiensi $\mathrm{P}$ akibat tingginya jerapan P (Prasetyo dan Suriadikarta, 2006). Kekurangan $P$ pada tanah Ultisol dapat disebabkan oleh kandungan $\mathrm{P}$ dari bahan induk tanah yang memang sudah rendah, atau 
kandungan $\mathrm{P}$ sebetulnya tinggi tetapi tidak tersedia untuk tanaman karena diikat oleh unsur lain seperti Al dan Fe.

Hasil analisis pupuk organik menunjukkan bahwa kandungan $\mathrm{C}$ organik dan $\mathrm{pH}$ ketiga jenis pupuk yang digunakan dalam penelitian sudah sesuai standar pupuk berdasarkan Permentan No. 70 tahun 2001 yaitu $\mathrm{C}$ organik cukup tinggi dan $\mathrm{pH}$ tergolong netral. Kandu-ngan $\mathrm{N}, \mathrm{P}_{2} \mathrm{O}_{5}$, dan $\mathrm{K}_{2} \mathrm{O}$ total masih di bawah standar atau belum sesuai aturan Permentan No.70 tahun 2001, kecuali $\mathrm{K}_{2} \mathrm{O}$ total pada pupuk bokashi kotoran ayam. Sedangkan untuk $\mathrm{C} / \mathrm{N}$ ratio hanya pupuk limbah sayuran pasar yang tidak sesuai standar.

Matriks hasil analisis statistik pada penelitian penelitian ini ditunjukkan pada Tabel 1. Matriks hasil penelitian (Tabel 1) menunjukkan bahwa perlakuan varietas dan interaksi antara varietas dan pupuk organik tidak berpengaruh nyata terhadap semua variabel. Perlakuan pupuk organik berpengaruh sangat nyata terhadap semua variabel pengamatan, yaitu jumlah cabang per tanaman, jumlah polong per tanaman, bobot biji per tanaman, bobot 100 biji, dan indeks panen.

Pengaruh varietas tidak berpengaruh nyata terhadap variabel pengamatan diduga karena tidak adanya perbedaan sifat antar varietas yang dipengaruhi oleh faktor genetik dan kondisi lingkungan. Menurut Toha et al., (2008) bahwa potensi hasil suatu varietas tidak dapat dipisahkan dengan tingkat adaptasi dan kondisi lingkungan tumbuh. Pernyataan tersebut didukung oleh Jedeng (2011), bahwa secara umum tinggi rendah suatu hasil atau produksi tanaman tergantung varietas, cara bercocok tanam, dan kondisi lingkungan tempat tanaman tersebut di tanam.

Pengaruh perlakuan pupuk organik terhadap variabel pengamatan disajikan pada Tabel 2. Berdasarkan Tabel 2 dapat diketahui bahwa perlakuan kontrol atau tanpa pupuk menunjukkan hasil terendah untuk semua variabel pengamatan. Hasil tertinggi pada semua variabel terdapat pada perlakuan pupuk kandang ayam, tetapi tidak berbeda nyata dengan perlakuan pupuk bokashi rumen sapi.

Hasil terendah pada semua variabel pengamatan terdapat pada perlakuan tanpa pupuk (kontrol) karena tanah ultisol memiliki sifat masam dengan kandungan Al tinggi yang mengikat kandungan unsur hara seperti $\mathrm{P}$ dan N. Hal tersebut menyebabkan unsur hara $P$ dan $\mathrm{N}$ untuk pertumbuhan menjadi tidak tersedia. Pemberian pupuk kandang ayam memberikan hasil terbaik pada jumlah cabang per tanaman, diduga karena tercukupinya ketersediaan unsur hara pada pupuk kandang ayam.

Tabel 1. Matriks Hasil Analisis Statistik Pengaruh Varietas Kacang Hijau dan Jenis Pupuk Organic terhadap Hasil.

\begin{tabular}{lccc}
\hline \hline \multicolumn{1}{c}{ Variabel Pengamatan } & Varietas & Pupuk & Varietas x Pupuk \\
\hline Jumlah cabang per tanaman & tn & $* *$ & tn \\
Jumlah polong per tanaman & tn & $* *$ & tn \\
Bobot biji per tanaman & tn & $* *$ & tn \\
Bobot 100 biji & tn & $* *$ & tn \\
Indeks panen & tn & $* *$ & tn \\
\hline \hline
\end{tabular}

Keterangan: $\mathrm{tn}=$ tidak berpengaruh nyata, ${ }^{* *}=$ berpengaruh sangat nyata

Tabel 2. Rata-rata Jumlah Cabang Per Tanaman, Jumlah Polong Per Tanaman, Bobot Biji Per Tanaman, Bobot 100 Biji, dan Indeks Panen pada Perlakuan Pupuk Organik.

\begin{tabular}{cccccr}
\hline \hline \multirow{2}{*}{ Perlakuan } & \multicolumn{5}{c}{ Variabel Pengamatan } \\
\cline { 2 - 6 } & $\begin{array}{c}\text { Jumlah Cabang } \\
\text { per tanaman }\end{array}$ & $\begin{array}{c}\text { Jumlah Polong } \\
\text { per tanaman }\end{array}$ & $\begin{array}{c}\text { Bobot Biji per } \\
\text { tanaman }\end{array}$ & Bobot 100 biji & Indeks Panen \\
\hline P0 & $3,55 \mathrm{c}$ & $1,44 \mathrm{c}$ & $0,39 \mathrm{c}$ & $3,96 \mathrm{~b}$ & $0,45 \mathrm{c}$ \\
P1 & $17,51 \mathrm{a}$ & $28,25 \mathrm{a}$ & $13,91 \mathrm{a}$ & $6,91 \mathrm{a}$ & $12,89 \mathrm{a}$ \\
P2 & $16,66 \mathrm{a}$ & $25,96 \mathrm{a}$ & $12,26 \mathrm{a}$ & $6,58 \mathrm{a}$ & $11,63 \mathrm{a}$ \\
P3 & $12,74 \mathrm{~b}$ & $19,29 \mathrm{~b}$ & $8,61 \mathrm{~b}$ & $5,77 \mathrm{a}$ & $7,53 \mathrm{~b}$ \\
\hline \hline
\end{tabular}

Keterangan : Angka-angka yang diikuti huruf yang sama pada kolom yang sama berarti tidak berbeda nyata pada uji DMRT dengan taraf kesalahan 5 persen.

P0: tanpa pupuk (kontrol); P1: pupuk kandang ayam; P2: pupuk bokashi rumen sapi; P3: pupuk bokashi limbah sayuran pasar. 
Jumlah polong dan bobot biji per tanaman tertinggi pada pupuk kandang ayam walaupun tidak berbeda nyata dengan pupuk bokhasi rumen sapi. Hal itu diduga karena sesuai hasil analisis, pupuk kandang ayam memiliki kandungan N, P, dan K yang tinggi. Hal ini diperkuat oleh pernyataan Widarawati dan Harjoso (2011), pembentukan dan pengisian polong dibutuhkan unsur N, P, dan $\mathrm{K}$ yang cukup untuk pembentukan protein pada biji.

Unsur $\mathrm{P}$ juga sangat penting dalam proses pembentukan biji. Bobot 100 biji tertinggi terdapat pada perlakuan pupuk bokashi kotoran ayam tetapi tidak berbeda nyata dengan pupuk bokashi rumen sapi. Hal ini diduga hara yang disumbangkan dari penambahan pupuk bokashi seperti fosfor dan kalium berpengaruh baik terhadap pembentukan biji. Menurut Hardjowigeno (2003) menjelaskan bahwa unsur $\mathrm{P}$ berperan salah satunya dalam pembentukan biji. Syafrina (2009) juga menyatakan bahwa funsi fosfor (P) bagi tanaman adalah merangsang pertumbuhan generatif, seperti pembentukan bunga dan buah, serta pengisian biji.

Menurut Gardner et al. cit. Pramudyani dan Djufry (2006) indeks panen merupakan nilai yang menggambarkan sistem pembagian hasil fotosintesis antara bagian vegetatif dengan biji, sehingga melalui indeks panen dapat diketahui kemampuan fotosintesis tanaman serta besarnya fotosintat yang ditranslokasikan ke biji kacang hijau. Pengaruh pupuk kandang ayam yang memberikan hasil terbaik pada variabel pengamatan menyebabkan indeks panen juga meningkat. Hal tersebut sesuai dengan pendapat Sedjati (2005) bahwa unsur K sangat penting dalam proses pembentukan biji bersama unsur $\mathrm{P}$ yang mampu mengatur berbagai mekanisme dalam proses metabolik seperti fotosintesis, respirasi, pembentukan bunga, perkembangan akar, dan transportasi hara dari akar ke daun. Menurut Murbandono (2000), unsur hara yang terdapat dalam pupuk organik lambat tersedia untuk pertumbuhan tanaman, tetapi dengan penggunaan pupuk organik perbaikan tanah akan terus berlangsung.

\section{Kesimpulan}

1. Antar varietas kacang hijau pada ultisol tidak menunjukkan perbedaan hasil.

2. Penggunaan pupuk organik mampu meningkatkan hasil pada berbagai varietas kacang hijau. Pupuk organik yang mampu meningkatkana hasil adalah pupuk kandang ayam dan pupuk bokhasi rumen sapi

\section{Ucapan Terima Kasih}

Penelitian ini didanai dari dana BLU Unsoed Tahun anggaran 2015, Skim Riset Institusi.

\section{Daftar Pustaka}

Ardjasa, W.S. 1994. Peningkatan Produktivitas Lahan Kering Marginal Melalui Pemu-pukan Fosfat Alam dan Bahan Organik Berlanjut Pada Pola: Padigogo-kedelai-kacang tungkak. Prosiding Seminar Nasional. Pengembangan Wilayah Lahan Kering Bagian I. Lembaga Penelitian Universitas Lampung.

Dinesh R, Srinivasan V, Hamza S, Manjusha A. 2010. Short-term incorporation of organik manures and biofertilizers influences biochemical and microbial characteristics of soils under an annual crop turmeric (Curcuma longa L.). Bioresource Technol. 101:4697-4702.

Hardjowigeno, S. 1993. Klasifikasi Tanah dan Padohenesis. Akademika Pressindo, Jakarta. 2003. Ilmu Tanah. Akademi Pressindo. Jakarta.

Jedeng, I.W. 2011. Pengaruh Jenis Dan Dosis Pupuk Organik Terhadap Pertumbuhan Dan Hasil Ubi Jalar (Ipomoea batatas (L.) Lamb.) Var. Lokal ungu. Tesis. Universitas Udayana, Denpasar.

Kementerian Pertanian. 2012. Kacang Hijau. Buletin Direktorat Budidaya Aneka Kacang dan Umbi.

Melati, M dan W. Adiyani. 2005. Pengaruh pupuk kandang ayam dan pupuk hijau Calopogonium mucunoides terhadap pertumbuhan dan produksi kedelai panen muda yang dibudidayakan secara organik. Bul. Agron. (33) (2) 8- 15.

Murbandono, L. 2000. Membuat Kompos. Penerbit Swadaya, Jakarta.

Pramudyani, L. dan F. Djufry. 2006. Respon tanaman padi dan gulma Fimbristylis miliacea (1.) Vahl. Pada pemberian pupuk nitrogen dan genangan air. J. Agrivigor 5: 259-269.

Sedjati, S. 2005. Kajian pemberian bokhasi jerami padi dan pupuk $\mathrm{P}$ pada kacang tanah. Jurnal Staf Pengajar. Fakultas Pertanian Universitas Muria Kudus. Hal 1-11. 
Setiawan, E. 2009. Pengaruh empat macam pupuk organik terhadap pertumbuhan sawi (Brassica juncea L.). Jurnal Embryo 6(1); 27-34.

Sevindrajuta. 2012. Efek Pemberian Beberapa Takaran Pupuk Kandang Sapi terhadap Sifat Kimia Inceptisol dan Pertumbuhan Tanaman Bayam Cabut. Artikel Ilmiah. Universitas Muhammadiyah Sumatera Barat Press. Sumatera Barat.

Syafrina, S. 2009. Respon Pertumbuhan dan Produksi Kacang Hijau (Phaseolus radiates L) pada Media Sub Soil terhadap Pemberian Beberapa Jenis Bahan Organik dan Pupuk Organik Cair. Skripsi. Fakultas Pertanian. Universitas Sumatera Utara.

Toha, H.M., K. Permadi, A.A, Daradjat. 2008. Pengaruh waktu tanam terhadap pertumbuhan, hasil, dan potensi hasil beberapa varietas padi sawah irigasi datarab rendah. Seminar Nasional Padi. Hal 581-599.

Trustinah, B.S, Radjit, N., Prasetiawati, dan Didik, H. 2014. Adopsi varietas kacang hijau di sentra produksi. Jurnal Iptek Tanaman Pangan. 9(1):24-38.

Utomo, A.R.P. 2015. Pemanfaatan kulit kacang tanah dan rumen sapi untuk pembuatan pupuk organik cair dengan penambahan jamur trichoderma (Trichoderma sp.). Jurnal Publikasi UMS.

Widarawati, R dan T. Harjoso. 2011. Pengaruh pupuk $\mathrm{P}$ dan $\mathrm{K}$ terhadap pertumbuhan dan hasil tanaman kacang hijau (Vigna radiata L.) pada media tanah pasir pantai. Jurnal Pembangunan Pedesaan. 11(1)::67-74 